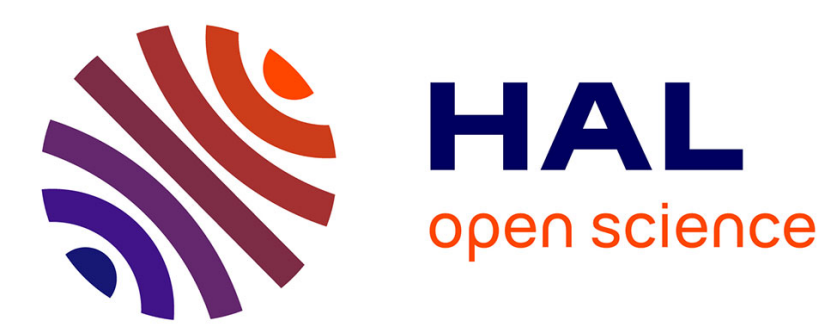

\title{
Wolbachia and recombination
}

Sylvain Charlat, Hervé Merçot

\section{To cite this version:}

Sylvain Charlat, Hervé Merçot. Wolbachia and recombination. Trends in Genetics, 2001, 17 (9), pp.493. 10.1016/S0168-9525(01)02475-1 . hal-02140466

\section{HAL Id: hal-02140466 \\ https://hal.science/hal-02140466}

Submitted on 31 May 2019

HAL is a multi-disciplinary open access archive for the deposit and dissemination of scientific research documents, whether they are published or not. The documents may come from teaching and research institutions in France or abroad, or from public or private research centers.
L'archive ouverte pluridisciplinaire HAL, est destinée au dépôt et à la diffusion de documents scientifiques de niveau recherche, publiés ou non, émanant des établissements d'enseignement et de recherche français ou étrangers, des laboratoires publics ou privés. 
cytoskeleton. Boldogh et al. ${ }^{1}$ now report that components of the Arp2/3 complex, previously implicated in the movement of intracellular pathogens such as Listeriamonocytogenes through the cytoplasm of infected cells, co-localize with mitochondria in budding yeast. Mutations in two genes for components of this complex result in decreased velocities and loss of directionality of mitochondrial movement, plus defects in mitochondrial morphology. In addition, actin polymerization around mitochondria depends on functional Arp2p, implying that, as for Listeria, actin nucleation and polymerization generate the force for mitochondrial movement. The Arp2/3 complex appears to be required specifically for actin-based mitochondrial motility, and is not identical to the previously characterized mitochondrial actin-binding protein (mABP), which seems to be needed independently to maintain connections between mitochondria and actin cables. Several binding partners for mABP on mitochondria have previously been identified, including two integral proteins of the mitochondrial outer membrane required for mitochondrial inheritance and morphology, $\mathrm{Mmm} \mathrm{mp}$ and Mdm10p.

In another recent study ${ }^{2}$, greenfluorescent protein (GFP)-labeled M mmlp was found to localize to punctate membrane structures 'adjacent' to mitochondrial nucleoids. Moreover, nucleoid integrity was dependent on $M M M 1$ function. Putting all these findings together, the evidence is growing for hard-wired connections between the cytoskeleton and mtDNA, through the mitochondrial membrane system. In contrast to textbook views of mtDNA as a 'relaxed' genome, mitochondrial inheritance seems to be carefully orchestrated by a system that reads and responds to cell polarity.

1 Boldogh, I.R. etal. (2001) Arp2/3 complex and actin dynamics are required for actin-based mitochondrial motility in yeast. Proc. Natl. Acad. Sci. U.S. A. 98, 3162-3167

2 Hobbs, A.E. etal. (2001) Mmm1p, a mitochondrial outer membrane protein, is connected to mitochondrial DNA (mtDNA) nucleoids and required for mtDNA stability. J. Cell Biol. 152, 401-410

\section{HowyJ acobs}

howy.jacobs@uta.fi

\section{Wolbachia and recombination}

The endocellular bacterium Wolbachia manipulates its hosts' reproduction in an impressive variety of ways: it can induce male killing, feminization, thelytokous parthenogenesis and cytoplasmic incompatibility $(\mathrm{Cl}$; embryonic mortality resulting from crosses between Wolbachiainfected males and uninfected females). Based on the distribution of these different phenotypes within Wolbachia phylogeny, it is classically argued that $\mathrm{Cl}$, the most widespread of the four, is likely to be ancestral, whereas the three others evolved several times. Such a view seemed acceptable, until J iggins et al. ${ }^{1}$, following Werren and Bartos ${ }^{2}$, showed that Wolbachia can recombine. As noted by these authors, Wolbachiarecombination makes it very tricky to infer the evolutionary history of the four different phenotypes from phylogeny, for two main reasons. First, gene phylogenies can be misleading, because they reflect the history of single genes, not necessarily that of the whole genome: Wolbachia strains appearing very distant in a phylogenetic tree might be closely related in reality. Second, the genetic machinery allowing a given Wolbachia to induce a particular phenotype can move between distant strains, so that distant Wolbachia could induce the same phenotype, although this phenotype might have evolved only once.

Similar problems emerge when considering $\mathrm{Cl}$. The mechanism underlying this phenomenon is unknown, but the current model is that it occurs when a sort of poison (termed mod, for modification), presumably deposited by Wolbachia in the germline of the males, is not neutralized by its antidote (termed resc, for rescue), presumably produced by Wolbachiain infected eggs, resulting in embryo death. The mod-resc (or poison-antidote) interaction is specific: several different mod-resc pairs (or compatibility types) exist. The evolutionary process involved in the emergence of new compatibility types from ancestral ones is unknown, buta basic prediction is that compatibility types will be more similar between closely related strains than between phylogenetically distant ones. This prediction can be tested through interspecific injection experiments, allowing the confrontation of mod-resc pairs of more or less closely related symbionts in a single host species. Recombination greatly complicates the interpretation of such experiments, for the two reasons presented above: first, strains might be more (or less) distant than inferred from phylogenetic markers and second, the mod-rescgenes themselves can move between strains.

Finally, recombination might affect our understanding of Wolbachia horizontal transfers (here we refer to the interspecific transfers of Wolbachia bacteria, not to
Wolbachia genes), which is mainly based on phylogeny. It is generally observed that Wolbachia and host phylogenies are not congruent: closely related Wolbachia strains can be observed in very distant host species. This pattern is usually interpreted as a result of Wolbachia bacteria being transferred between distant hosts. Recombination suggests an alternative interpretation: if genes can move between different host species through vectors such as viruses, horizontal transfers involving whole and viable bacteria might be much less frequent than generally believed.

Now, does recombination throw Wolbachia research into chaos? Not necessarily. Phylogenetic inferences based on unique genes must be considered very cautiously, but the use of several independent markers, sufficiently distant within the genome, should circumvent these difficulties.

$1 \mathrm{~J}$ iggins, F.M. et al. (2001) Recombination confounds interpretations of Wolbachia evolution. Proc. R. Soc. London B Biol. Sci. 268, 1423-1427

2 Werren, J.H. and Bartos, J.D. (2001) Recombination in Wolbachia. Curr. Biol. 11,431-435

\section{Sylvain Charlat}

charlat@ijm.jussieu.fr

Hervé Merçot

mercot@ccr.jussieu.fr 